\title{
Posterior Vitreous Detatchment
}

National Cancer Institute

\section{Source}

National Cancer Institute. Posterior Vitreous Detatchment. NCI Thesaurus. Code C118721.

The separation of the vitreous from the retina. 